The groundwork for the shift was laid two years ago, when the centres agreed to divert five per cent of their budgets to a central, DM150-million strategy fund, to which they have to apply competitively (see Nature 387, 837; 1997). “The strategy fund has prepared the ground for more collaboration and competition between the centres," says Detlev Ganten, scientific director of the Max Delbrück Centre for Molecular Medicine in Berlin and head of the HGF. "But now we will have a de facto global budget."

Most HGF members welcome the changes, hoping that they will sharpen the centres' scientific profiles at a time when the Wissenschaftsrat, Germany's science council, has begun a systematic evaluation of the HGF. "Provided that basic research is not excessively damaged, it is certainly the right development," says Hans-Günter Afting, director of the National Research Centre for Environment and Health in Munich.

But some of the HGF's research may have to find a new home. The Bonnbased National Research Centre for Information Technology, for example, will leave the HGF in 2001 and join the Fraunhofer Society, Germany's organization for applied research. According to Ganten, a further reduction of the number of national research centres is "within the bounds of possibility".

Quirin Schiermeier

\title{
Nuclear safety and biotech boosted in Japan's budget
}

Tokyo

Biotechnology, venture businesses and nuclear safety all receive extra support in Japan's latest supplementary budget, approved by the parliament last week, which is aimed at putting the nation's economy on a full recovery track.

As well as a strong emphasis on public works projects, the supplementary budget — the second this year — includes generous support for science. This is largely a result of prime minister Keizo Obuchi's Millennium Project, which seeks to promote new industries in areas such as biotechnology, information sciences and environmental technology (see Nature 401, 313; 1999).

The supplementary budget totals $¥ 6.79$ trillion (US\$66 billion), of which $¥ 907.6$ billion is earmarked for science and technology, and $¥ 773$ billion for supporting small and medium-sized businesses.

The Science and Technology Agency (STA) will receive $¥ 16.4$ billion for life sciences, including $¥ 4.3$ billion for nuclear magnetic resonance facilities being built at the new headquarters of the Genomic Sciences Centre, ¥1.2 billion for proteomics research, and $¥ 2.4$ billion for the analysis of human complementary DNA (cDNA). The agency will also receive $¥ 46.1$ billion for additional efforts in nuclear safety, following the accident at a uranium-processing plant in Tokaimura, Ibaraki Prefecture.

The Ministry of International Trade and Industry (MITI), which takes over some of the nuclear safety responsibilities of the STA in 2001, and the Ministry of Health and Welfare will receive $¥ 30.8$ billion and $¥ 11.6$ billion, respectively, for nuclear safety research.

MITI will receive $¥ 12.5$ billion for biotechnology-related research, including proteomics projects, while $¥ 35.6$ billion will support venture businesses, particularly entrepreneurial activities at universities.

A budget boost for the Ministry of Agriculture, Forestry and Fisheries will speed up the rice genome sequencing project by almost four years (see Nature 401, 102; 1999).

Public works projects include building at national universities, such as the new campus at Kyoto University. They also include plans for new life-sciences-related research institutes.

The budget brings Japan's science spending beyond $¥ 17$ trillion, as promised by the Science and Technology Basic Plan, which pledged to double science spending between 1996 and 2000.

\section{Wellcome Trust backs Rutherford to host synchrotron}

London

Britain's Wellcome Trust has declared its preference that a new Anglo-French synchrotron source should be built at the Rutherford Appleton Laboratory (RAL) in Oxfordshire. The trust is providing a substantial proportion of the construction costs.

But the statement coincides with an announcement by the UK government that the long-awaited decision over a home for the facility, known as Diamond, will be delayed again to allow two new reports on the candidate sites to be commissioned.

Trade and industry secretary Stephen Byers also said last week that he has asked John Taylor, the director-general of research councils, to seek the views of synchrotron users "on what they see as the key issues of relevance to a decision on the site".

An engineering survey and report are also being commissioned from consultants for the two potential sites - at RAL and at Daresbury Laboratory near Manchester. A decision is now expected in mid-January.

Science minister Lord Sainsbury acknowledged in a letter to the Financial

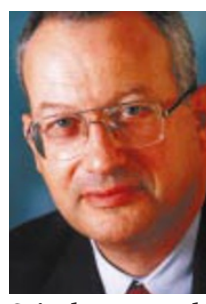

Times newspaper this week that there were "difficult scientific considerations to resolve" about the synergy between the synchrotron and the existing neutron spallation source at RAL, "as well as issues concernSainsbury: tough ing the suitability of the questions over two sites".

science synergy. In its statement last week, the Wellcome Trust says it prefers RAL because it believes that greater scientific benefits would result from a location close to the existing neutron source and to Medical Research Council units and the University of Oxford.

But union officials and some senior synchrotron scientists say this factor is a "small but not overriding consideration", given the small numbers of scientists that would benefit. The trust has also generated anger among supporters of Daresbury by suggesting there are greater planning risks associated with the northern site.

Chris Brough, assistant director of plan- ning for the area, criticizes "unsubstantiated assertions" by the trust's planning consultants about potential drawbacks of the Daresbury site. He says they have failed to do the "most basic thing that any planning consultant worth its salt would do - contact the local planning authority".

"It's foolish to say we are high risk [when] we have a sympathetic development agency," says Sue Smith, a union representative at Daresbury. "RAL does not even have potential [outline] planning permission."

The dispute over where Diamond should be sited has raised fears that choosing the Rutherford site would eventually lead to the closure of Daresbury and further deepen Britain's north-south divide.

Daresbury appears to have strong support from local government, local Members of Parliament, and Byers. The unions say they have a letter from an Oxfordshire councillor expressing concern at the prospect of economic "overheating" in the area around Rutherford and at problems of providing housing for the existing influx of workers into the region.
Natasha Loder 